UNIVERSITY

OF DEBRECEN

FACULTY OF

HEALTH

NYÍREGYHÁZA

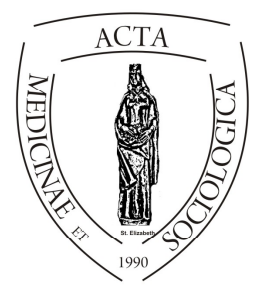

ACTA

MedSoC

VOLUME 7.

2016

\title{
A vidéki térségek endogén fejlődési lehetőségei
}

\author{
Ludescher Gabriella \\ Debreceni Egyetem Egészségügyi Kar \\ Társadalomtudományi Tanszék
}

\section{Facilities for the endogenous development of rural territories}

\begin{abstract}
The endogenous development enjoys great popularity in the world of regional sciences and within this the theory of territorial capital is an even narrower aspect of it. In the first part, this article presents the significance of the factors that play an important role in the endogenous development of rural regions, like social, economic factors and soft elements. Hencefore it analyzes the important aspect of endogenous development, the territorial capital and its various definitions. The starting point of the study is the theory of territorial capital which has been created so far. The author tests the suitability of the existing statistical method used for the measurement of rural territories. Throughout the examination it was found that the territories existing under the rating of NUTS IV. and V. possess different elements of territorial capital than those of NUTS II. and III. In the core of the article the author, according to the previously mentioned remark, considers it justifiable to create and systematize the elements of rural territorial capital and to work out the quantitative and qualitative methods of it. Finally, in its last part the study deals with the new approaches of the rural territorial capital, which enables the deep survey of rural territories.
\end{abstract}

Keywords: edogenous development, rural territories, territorial capital

DOI: $10.19055 / \mathrm{ams} .2016 .7 / 22-23 / 3$ 


\begin{abstract}
Absztrakt: Az endogén fejlődés nagy népszerüségnek örvend a regionális tudományok világában és ezen belül is egy szükebb aspektusa a területi tőke elmélete. A cikk első részében a vidéki térségek endogén fejlődésben fontos szerepet játszó tényezők mint például a társadalmi, gazdasági puha elemek fontosságát mutatja be. Továbbá elemzi az endogén fejlődés fontos aspektusát, a területi tőkét és annak különböző féle meghatározását. A tanulmány az eddig megalkotott területi tőke elméletéből indul ki. A szerző a meglévő statisztikai módszer alkalmasságát vizsgálja a vidéki térségek mérésére. A vizsgálat során arra a következtetésre jutott, hogy a NUTS IV. és V. besorolás alatti területi nagyságok más területi tőke elemekkel rendelkeznek, mint a NUTS II. és III. területek. A cikk magjában a szerző az előbb említett észrevételének megfelelően indokoltnak látja a vidéki területi tőkeelmeinek megalkotását, rendszerezését és módszertani eszközeinek kvantitatív, kvalitatív kidolgozását. Végezetül a tanulmány az utolsó részében foglalkozik a vidéki területi tőkeelemek újszerű megközelítési módszereivel, amely lehetővé teszi a rurális térségek mélyreható felmérését.
\end{abstract}

Kulcsszavak: endogén fejlődés, rurális térség, területi tőke

\title{
Bevezetés
}

Fontos a vidék területi tőkeelmeinek tárgyalása elött megismerni a vidéki térségek endogén tényezőit. A kifejezés „,...endogén alatt a közgazdaságtanban az olyan tényezőket értjük, amelyek nem örököltek (,nem Istentől valók”), hanem a gazdasági tevékenység által tudatosan hozták létre azokat. A regionális tudományban a régión belül tudatosan kialakított, az egyedi tényezőkön alapuló, alulról szerveződő, a helyi társadalom aktív részvételével zajló közösségi fejlesztéseket, akciókat tartjuk endogén jellegünek" (Lengyel 2012, 145. o.).

Egy adott terület gazdasági szerkezete és folyamatai komplexebben vizsgálható, ha a mérhető, számszerüsíthető elemek mellett immateriális tőke elemeket is beemelünk. Ezeket a tényezőket gyakran a helyi szakemberek, döntéshozók is figyelmen kívül hagyják, mivel nehezen mérhetőek a látens mivoltuknak köszönhetően. Ezzel összhangban megfigyelhető, hogy egyre több kutatás kiemeli a puha tényezők fontosságát egy terület gazdasági fejlődésében. Az utóbbi évtizedekben a hazai kutatásban készültek olyan tényképek egy-egy régióról, illetve agglomerációkról vagy kis kistelepülések csoportjairól (Gáspár 2001 [1986], Ignits - Kapitány 2007, Kovács K. 1990, Kovács T. 2008, Kuczi 1998, Ludescher 2010, Szörényiné Kukorelli 1997), melyek puha és kemény tényezőket egyaránt figyelembe vettek. Továbbá a vidéki térségek fejlesztése céljából Enyedi (1997) is meghatározta a sikerességi tényezőket, ahol megjelenek a materiális és immateriális tényezők fontossága. 
A regionális tudomány fejlődésével az elmúlt évtizedben a puha és kemény, illetve materiális és immateriális tényezők átfogó mérésére megalkották (Camagni 2009, Rota 2010; Veneri 2011) a területi tőke fogalmát.

\section{Tőkék és a területi tőke}

Fontos megemlíteni azt, hogy a területi tőke fogalma milyen elméleti dimenzió mentén jött létre és hogyan kapcsolódik más tőkefajtákhoz. Bourdieu (1998), Putnam (2000) és Coleman (1988) munkái alapján beszélünk először tőke fajtákról, melyet ők definiálnak és csoportosítanak, mint például társadalmi (ezen belül kapcsolati), kulturális (humán tőke) és gazdasági tőkeként.

A regionalisták a fent említett tőkék összességének kifejezésére a legalkalmasabbnak, legkifejezőbbnek a területi tőke fogalmát tartották. A területi tőke nem illeszthető be a tőketípusok egyszerü folytatásaként, hanem inkább ebben összesítendök a láthatatlan és a fizikai komponensek (Tóth 2010).

A tőkeelemek elemzésére kialakult elmélet és módszertan, mely a puha tényezőket is figyelembe veszi és átfogóan mérhetővé teszi. A területi tőke lényege, hogy a korábban nem mért immateriális javakat és a materiális javakat együttesen veszi figyelembe és mindkettőnek egyforma értéket tulajdonít (Fabbro Mesolella 2010).

Ezen tőkéket a regionális kutatók máshogy közelítik meg, mint a hazai és nemzetközi vidékkutatók. A magyar vidékkutatásokban megjelenik a társadalmi tőke fogalma. Kis (2006) e töke fontosságát mutatja be a közösség és a vidékfejlesztésben. A társadalmi töke megjelenésével egyidejüleg megjelent a hálózatkutatás és annak módszerei, mert a társadalmi tőke hálózatokhoz kapcsoltan értelmezik, e kapcsolatok összességében manifesztálódnak. Az utóbbi évtizedben meg is ismerhetünk több vizsgálatot a hálózatkutatással kapcsolatban és ezen belül is a településhálózatok, közlekedési hálózatok, kkv-hálózatok (Beluszky-Győri 1999, Rechnitzer 2002, Novotny 2003, Rechnitzer-Grosz-Csizmadia 2003, Kovács T. 2005, Somlyódiné 2006, Jóna 2016) módszerei terjedtek el a legjobban, a regionális tudományokban. Csurgó és társai (2009) kutatásuk során európai és hazai vidéki hálózatokat bemutató és összehasonlító tanulmányokban vizsgálják, hogy miként jelenik meg a hálózat a vidékszociológiai kutatásokban. Vizsgálataik során arra a következtetésre jutottak, hogy a hazai hálózatkutatók közül csak kevesen fordultak a vidék kérdésköre felé. Ezen regionális kutatások hagyományos módszerei nem törték be magukat a vidékkutatási vizsgálatok tárházába. Megfigyelhető az is, hogy a közösségfejlesztők a lokális közösségek fejlesztésében a társadalmi tőke és a hálózatkutatás módszereit gyakran használják. 
Nemzetközi vidékkutatók tárházából is hiányzik a területi tőke fogalma, ha meg is jelenik a kidolgozottság hiányát szenvedi. Steiner, Atterton (2015) és Wilson (2012), a tőkék összeillesztésére tesznek próbát. Vizsgálatuk során kifejtik, hogy a gazdasági, társadalmi és a környezeti tőkéket ajánlatos „összeragasztani” ahhoz hogy a közösség összetartson, ezenfelül mindegyik tőkének önmagában is az a szerepe, hogy társadalom jól működjön (1. ábra). Úgy vélik, hogy ezen tőkék együttese társadalmi rugalmasságot hoz létre, amely nem támaszkodhat kizárólag csak gazdasági vagy társadalmi tényezőkre (McManus és szerzőtársai 2012).

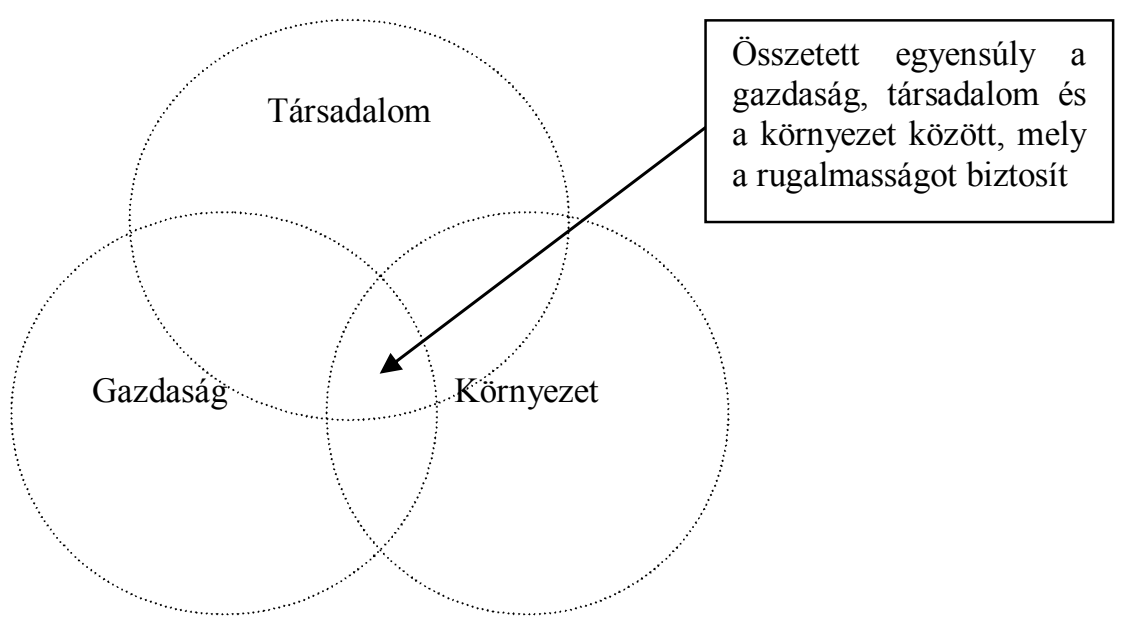

1.ábra: A társadalmi rugalmasság kulcs komponensei.

(Forrás: Steiner, Atterton 2015, 33. o.)

Más vidékkutatók (Sánchez-Zamora és társai 2014) azt elemzik, hogy egy rurális terület dinamikus sikerességéhez a fenti tőkékre (gazdasági, humán, társadalmi és kulturális) van szükség, valamint ezt kiegészítik még a környezeti tőkével. Az andalúziai térségben végzett vizsgálatuk során ezen tőkéket konceptualzálták és operacionalizálták, azaz lebontották, hogy melyik tőke alatt mit értenek és azokat hogyan lehet mérhetővé tenni.

\section{A területi tőke fogalma és elemei}

Számos kutató munkásságának megismerése után nagyfokú ismerettel rendelkezünk a tőkék fogalmi, osztályozási, funkciói, kapcsolati, hálózati és elemzési módszereivel összefüggően. Ennek ellenére azzal a hiányérzettel küszködünk, 
hogy empirikus kutatás során nem jelennek meg ezek az ismeretek a vidékkutatásban. Felvetődik a kérdés, hogy talán azért nem használják, mert alkalmatlanok a gyakorlati alkalmazásra, mert módszertanilag nincs kidolgozva a vidéki kutatás számára, vagy talán olyan elemeket tartalmaz, melyek a vidéken nem léteznek, illetve nem mérhetőek.

Jelen tanulmány kísérletet kíván tenni a fent említett kérdések megválaszolására, azaz alternatívát kíván nyújtani a puha és a kemény tényezők mérésére vidéki térségekben. Szakirodalommal összefüggően a tanulmány egy térség gazdasági, társadalmi, kulturális, humán és környezeti tőkefajták összességét területi tőkeként tekinti. A területi tőkefogalma lassan egy évtizede jelen van, de még mindig nincs konkrét definíció és gyakran találunk tartalmi átfedéseket és értelmezésbeli eltéréseket. Jóna (2013) tanulmányában a területi tőke fogalmi elemeit, osztályozását, modelljeit, definíciós kísérleteinek eredményeit és módszertani eljárások legfőbb jellemzőit mutatja be. Elsőként az OECD (2001) Territorial Outlook címü jelentésben definiálták a területi töke fogalmát. A modell a területi tőke három forrásáról tesz említést a látható tényezőkről, láthatatlan összefüggésekről és megfoghatatlan tényezőkről (1. táblázat). Az OECD (2001) hangsúlyozza a területi tőke koncepciójában az endogén fejlődés társadalmi, kulturális háttérfeltételeit.

\begin{tabular}{|c|c|c|}
\hline $\begin{array}{l}\text { Látható (fizikai) } \\
\text { tényezők }\end{array}$ & Láthatatlan összefüggések & $\begin{array}{l}\text { Megfoghatatlan } \\
\text { (immateriális) tényezők }\end{array}$ \\
\hline $\begin{array}{l}\text { Földrajzi fekvés } \\
\text { Terület nagysága } \\
\text { Termelési tényezőkkel } \\
\text { való ellátottság } \\
\text { Klíma } \\
\text { Tradíciók }\end{array}$ & $\begin{array}{l}\text { Hallgatólagos megállapodás } \\
\text { Szokások és informális } \\
\text { szabályok, melyek bizonyta- } \\
\text { lan feltételek között is lehe- } \\
\text { tővé teszik a gazdaság sze- } \\
\text { replöi számára az együttmü- } \\
\text { ködést }\end{array}$ & $\begin{array}{l}\text { Intézmények } \\
\text { Szabályok } \\
\text { Szokások } \\
\text { Maguk a termelők } \\
\text { Kutatók } \\
\text { Helyi politikusok }\end{array}$ \\
\hline $\begin{array}{l}\text { Természeti erőforrások } \\
\text { Életminőség } \\
\text { Méretgazdaságossági } \\
\text { előnyök }\end{array}$ & $\begin{array}{l}\text { Szolidaritás } \\
\text { Kölcsönös segítségnyújtás } \\
\text { Az új gondolatok elfogadása } \\
\text { kisebb közösségekben }\end{array}$ & $\begin{array}{l}\text { Utóbbi két csoport } \\
\text { valamilyen kombinációja, } \\
\text { amely bizonyos kreativi- } \\
\text { tást és újítást tesz lehetővé. }\end{array}$ \\
\hline
\end{tabular}

Forrás: Jóna szerkesztése 2013 OECD 2001, 15. o alapján

1.táblázat: A területi tőke forrásai az OECD szerint. 
Kunzmann (2011) és Stein (2010) írásaikban azt hangsúlyozzák, hogy a területi tőke három forrása közösen járulnak hozzá a regionális versenyképesség javulásához és a regionális fejlödéshez. Zonneveld és Waterhout (2010) a területi tőkét két változóra bontják keményre, melyek alatt strukturális jellemzőket értenek, valamint puha változókra, mely közé sorolják a társadalmi-kulturális jegyeket. Fontosnak tartom Camagni (2009) területi tőkeelméletéről és alkalmazhatóságáról szót ejteni. Ö volt az első, aki megkísérelte kidolgozni a területi tőke definícióját. Egy átfogó modellt alkotott, az osztályozásánál három összetevőt határoz meg (tárgyit, vegyes és nem tárgyi javakat) és kilenc elemet definiál és úgy véli, hogy ez a kilenc tőkefajta befolyásolja leginkább a helyi lehetőségeket. Camagni modell felépítésének két fő része a „hagyományos négyzet” és az „innovatív kereszt" E modell az Európai Unió fejlesztéspolitikai stratégiai alkotásához, tervezési fázisához egyik alkalmazott modell. A modell az endogén fejlődést hangsúlyozza, helyközpontú és aluról szerveződő elven müködik. Bodor és Grünhut (2014) írásukban dilemmákat fogalmaznak meg a Camagni (2009) területi tőke modelljének alkalmazhatóságáról. Véleményük szerint a modell két fö része a „hagyományos négyzet”és az „innovatív kereszt” nem válaszhatók el egymástól. Camagni társadalmi tőke és a kapcsolati tőke problémájára hívja fel a figyelmünket Bodor és Grünhut (2014) munkájuk során azzal, hogy ugyan Camagni a területi tőke modelljében különbséget tesz a kapcsolati tőke és a társadalmi tőke fogalmai között, de a fejtegetések végén a fogalmak ténylegesen nem különülnek el egymástól, csak inkább zavaró redundanciát okoznak. Egyet értek a kritikát megfogalmazókkal, hogy „...teljes térségek társadalmainak kollektív tulajdonságait „kapcsolati tőkének” hívni legalábbis szokatlan és talán félrevezető, továbbá magában hordozza annak veszélyét, hogy a valóságot erösen leegyszerüsítve helyi társadalmakat, közösségeket homogénnek tekintsünk" (Bodor-Grünhut, 2014, 9. o.).

A dilemmák nagyon erősek Camagni (2009) területi tőke modelljének a gyakorlati alkalmazhatóságával kapcsolatban, mivel nem tudja elkülöníteni a társadalmi tőkét a kapcsolati tőkétől, nem reflektál az individuális és kollektív társadalmi tőke problémájára, és a társadalmi tőke pozitív hatását vizsgálja csak (Bodor-Grünhut, 2014). Emellett arról nem is beszélve, hogy a vidéki térségek területi tőkéjének feltárásában csupán csak támpontot tud adni.

Tóth (2013) munkája során összefoglalta szerzők (Capello, Camagni, Lengyel - Szakálné Kanó, Milone et al. stb.) modellje szerint egyes tényezők megjelenését az endogén modellekben. Megállapítható, hogy a magán álló-, a humán, a társadalmi, a természeti, a kulturális, a kapcsolati és az infrastrukturális tőke a legfontosabb tőketényező. Emellett az is megállapítható, hogy minden modell más tényezőkkel és tőkefajtákkal dolgozik, így az empirikus elemzések során eltérnek a modelleknek megfelelően eltérő indikátorrendszerek jönnek létre. 
A fentiek alapján látható, hogy a területi tőke paradigmája összetett megközelítésen alapul ezért a vizsgálatára több kutatási módszertan is a rendelkezésünkre áll. Capello (2007) megalkotta a MASST modellt (macroeconomic, sectoral, social and teritorial model), mely alkalmas elörejelzést adni egy régió (NUTS II.) növekedési lehetőségeire, így a modell segítségével vizsgálható egy régió területi tőkeállománya. A MASST modell ökonometriai modell nemzetgazdasági összetevőket, illetve regionálisan differenciált összetevőket vizsgálja endogén és exogén, magyarázó és függő változók segítségével. A modell gyakorlati alkalmazása még nem nagyon terjedt el, így a használhatóságával kapcsolatos tapasztalatok visszacsatolására nem támaszkodhatunk. Emellett a modell nem is alkalmas arra, hogy gyakorlatban egy vidéki térség területi tőkéjét feltárjuk annak ellenére, hogy jól kidolgozott ökonometriai módszerrel rendelkezik. Kovács - Bodnár (2016) a PLS-útelemzés segítségével vizsgálják az endogén fejlődés értelmezését vidéken. A látens változók felhasználásával olyan regressziós modellt alkalmaznak, ami képes magyarázni, hogy mely tényezők, milyen mérték-

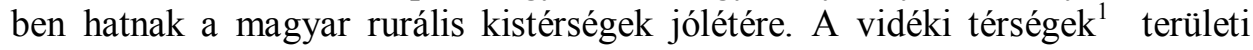
tőkeállományának vizsgálatakor a kvantitatív módszerek mellett szükséges kvalitatív szociológiai módszert alkalmazni, mely feltárja a puha tényezőket, mint például a területi miliőt és identitást, a lokális bizalmat, az összetartozást, a társadalmi normákat, habitusokat és közösségi hajtóerőt.

\section{Az endogén fejlődés és a területi tőke mérési módszerei}

Területi tőke meghatározási módjainak áttekintése után továbbra is szükségesnek tartja a tanulmány a kisebb térségek területi tőkéjének elemeit és felmérési módszereit megkülönböztetni a regionális elemektől és felmérésektől, ezt alátámassza Zonnenveld és Waterhout $(2005,2010)$ megállapítása is, hogy minden területnek sajátos tőkekészlete van.

\footnotetext{
${ }^{1}$ A vidéki településnek számít 10.000 fö alatti lakónépesség vagy $120 \mathrm{fő} / \mathrm{km}^{2}$ alatti népsürüség, illetve vidéki kistérségnek (térségnek) nevezzük azt az adott területet, melynek a népességének kevesebb mint 50\%-a él 120 fö/ $\mathrm{km}^{2}$ népsürüséget meghaladó településen. Ezt a lehatárolást kiegészíthetjük Csatári (2000) munkája alapján településszerkezeti besorolással „,aprófalvas”, „tanyás”, „mezővárosi”, és kisvárosi”, illetve lakosságarány alapján „erőteljesen vidékies”, „vidékies”, „,városias” és „,erőteljesen városias” kistérség típusok segítségével.
} 
Jól ismert, hogy nagyon fontos mutatóként használják a GDP-mutatókat egy adott térség fejletségének méréséhez és a területek összehasonlításához. A jelen tanulmány viszont fel kívánja hívni a figyelmet arra, hogy a NUTS II. és III. besorolás alatti területi nagyságokat is fontos megvizsgálni, amik ugyan nem rendelkeznek GDP-mutatókkal, de e fontos mutató helyett rendelkezésre áll a területi töke, mely nem csak a helyi gazdasággal foglakozik, hanem a társadalom kemény és puha mutatóit összesíti. A NUTS IV. és V területi tőke ismeretében láthatóvá válik e területek fejletsége és lehetősége, valamint az „egyszerü” statisztikai mutatókon túlnyúlnak és megmutatják a térségben rejtett adottságokat.

Az eddig bemutatott területi tőke tényezők alapján látható, hogy egyik módszer sem alkalmas önmagában egy kisebb térség, illetve település területi tőkéjének felmérésére. A vidéki területi tőke elemeinek összeállitásához az OECD (2001) területi töke elemei adtak kiindulópontot és erre alapozva új elemeket beemelve hozta létre jelen tanulmány szerzője a vidéki, települési területi tőke elemi modelljét (2. ábra). A vidéki területi tóke elemei sokban hasonlítanak az OECD (2001), Camagni (2009), illetve Zonneveld és Waterhout (2010) területi tőke elemeihez, de azoktól viszont eltér abban, hogy lehetőséget ad arra, hogy egy kisebb térség (település, vidéki járás) tőke elemeit megmérjük és megállapítsuk a vizsgált terület területi tőkéjét. Továbbá a módszer segítségével láthatóvá válik, hogy a NUTS III-on belül egy településen milyen hiányok és pozitívumok vannak.

Jelen tanulmány szerzőjének véleménye szerint egy nagyobb térség társadalmi, kapcsolati és közösségi tőkéje nagyon nehezen mérhető, mivel ezeket a megfoghatatlan, láthatatlan puha tényezőket kvalitatív módszerek (interjúk, résztvevői megfigyelések, narratív elemzések, fókuszcsoportos beszélgetések stb.) segítségével lehet csupán (!) feltérképezni. A kutatók nem szívesen használják ezt a módszert a komplexitása miatt a kvantitatívval ellentétben. Ugyan is a kvalitatív módszer mélyreható, kis elemszámú, de ennek ellenére nagyon időigényes, valamint a mintavételi eljárása nem reprezentatív, így nem tudnak az eredményekből nagy általánosságokat megfogalmazni.

A másik probléma, hogy a vizsgálati koncepció újszerüsége miatt a területi tőkével kapcsolatos elemző kutatással még nem igen foglalkoztak Magyarországon. Négy alkalmazott kutatás jelent meg ez idáig, de ezek közül kettő azokat a fontosabb tényezőket kívánja feltárni, mely legnagyobb mértékben hatnak egy térség fejlődésére. Az egyik ilyen szerzőpáros Kovács - Bodnár (2016), akik a látens változók vizsgálatai során azt az eredményt kapták, hogy a magán állótőkét legerősebben a társadalmi tőke, másodsorban a sikerességi tényezők közé tartozó infrastrukturális tőke befolyásolja. Jóna (2013) az ország kistérségeit vizsgálta, és többváltozós regresszió elemzéssel megállapította, hogy milyen mértékben határozza meg a hét tőketényező az általa alkotott területi tőkét. 2011-ben Tóth a magyar középvárosok teljesítményét vizsgálta a területi töke tükrében, a materiális és az immateriális faktorok között korrelációs együtthatók 
alapján vizsgálta az összefüggéseket. A település közmüvelődésével kapcsolatos háttértényezők, valamint a felsőoktatási kapacitás és a mozi- és a színházlátogatás között vélt a legerősebb korrelációt felfedezni. 2016-ban pedig Czakó és Dőry Győrre vonatkozóan vállalati szintü vizsgálatot végeztek Camagni ,innovatív kereszt'tőkecsoportja alapján és a benne lévő tőkeértékek megjelenési formáit szemléltetik a városi környezetben tevékenykedő vállalkozói rétegben.

Tóth $(2013,2014)$ a területi töke empirikus kutatásával összefüggő publikációkat elemezte az alapján, hogy a szerzők, milyen alkalmazott statisztikai módszereket használtak, milyen típusú területeken végeztek és mely időszakokban. Ez segítségül szolgált a jelen cikk szerzőjének abban, hogy alátámassza azt az érvelését, hogy eddig a kutatók kizárólag NUTS II. és III. területeket vizsgáltak, valamint hogy kizárólag statisztikai módszerekre és ezen belül is többnyire meglévő statisztikákra támaszkódnak (másodelemzést végeznek). Ez a tendencia Tóth (2014) empirikus vizsgálatánál is megfigyelhetö, mivel az egyes tőkefajtákhoz indikátorokat kapcsolt, mely a külföldi empirikus elemzésekben fellelhető ajánlásokra támaszkodik. A jelen tanulmány nem ért egyet egyes tőké indikátoraival, mint például „kapcsolati töke (összeköttetés feltételei) indikátorai: ezer lakosra jutó személyi számítógépek száma, db; ezer lakosra jutó mobil előfizetések száma, db.; ezer lakosra jutó internetfelhasználók száma, fö; ezer lakosra jutó személygépkocsik és motorkerékpárok száma, db.” (Tóth, 2014, 11.). Továbbá nem ért egyet a jelen tanulmány a fent említett szerző és nemzetkőzi szakirodalom által alkalmazott humán töke (oktatás, szabadalmak), kulturális tőke (közmüvelödés) és a társadalmi tőke (biztonság, szegénység, segélyek) indikátoraival és e típusú leegyszerüsítéseivel. A fent említett tőkék indikátorai segítségünkre lehetnek, de önmagukban alkalmazás kifejezetten veszélyes, mert nem valós állapot ismerhetünk meg rajtuk keresztül. A kapcsolati tőke esetében például fontos, hogy kivel tartanak kapcsolatot az egyének, a gazdasági és társadalmi szervetek, valamint a kapcsolataik milyen típusú, minőségü és intenzitású.

\section{Vidéki térségek, illetve települések endogén fejlődési elemei}

A tanulmány szükös kerete miatt a cikk nem tér ki a tőkék operacionalizálására és a kvalitatív módszertan részletes leírására. A módszerek sokszínüségének áttekintése után a tanulmány a vidéki területi tőke elemeinek felosztásakor (2. ábra) az OECD (2001) hármas csoportosítását választotta, mert ez átláthatóbbá teszi a tőkekomponenseket és kifejezi társadalmi megragadhatóságát. Fontos megemlíteni, hogy a felosztási kategória elemei eltérnek az OECD (2001) által 
megfogalmazott elemektől, valamint felosztásoknál módszertani eszközök vannak megjelölve.

A vidéki tőke elemeket (2. ábra) a szerző egy tölcsérben ábrázolta a szerint, hogy a látható és a láthatatlan tényezők érintkeznek és ezen elemek hatásai lefolynak, begyürüznek a megfoghatatlan tényezőkhöz, ahol ismét hatást, változást váltanak ki és így kialakítják a területi tőkét.

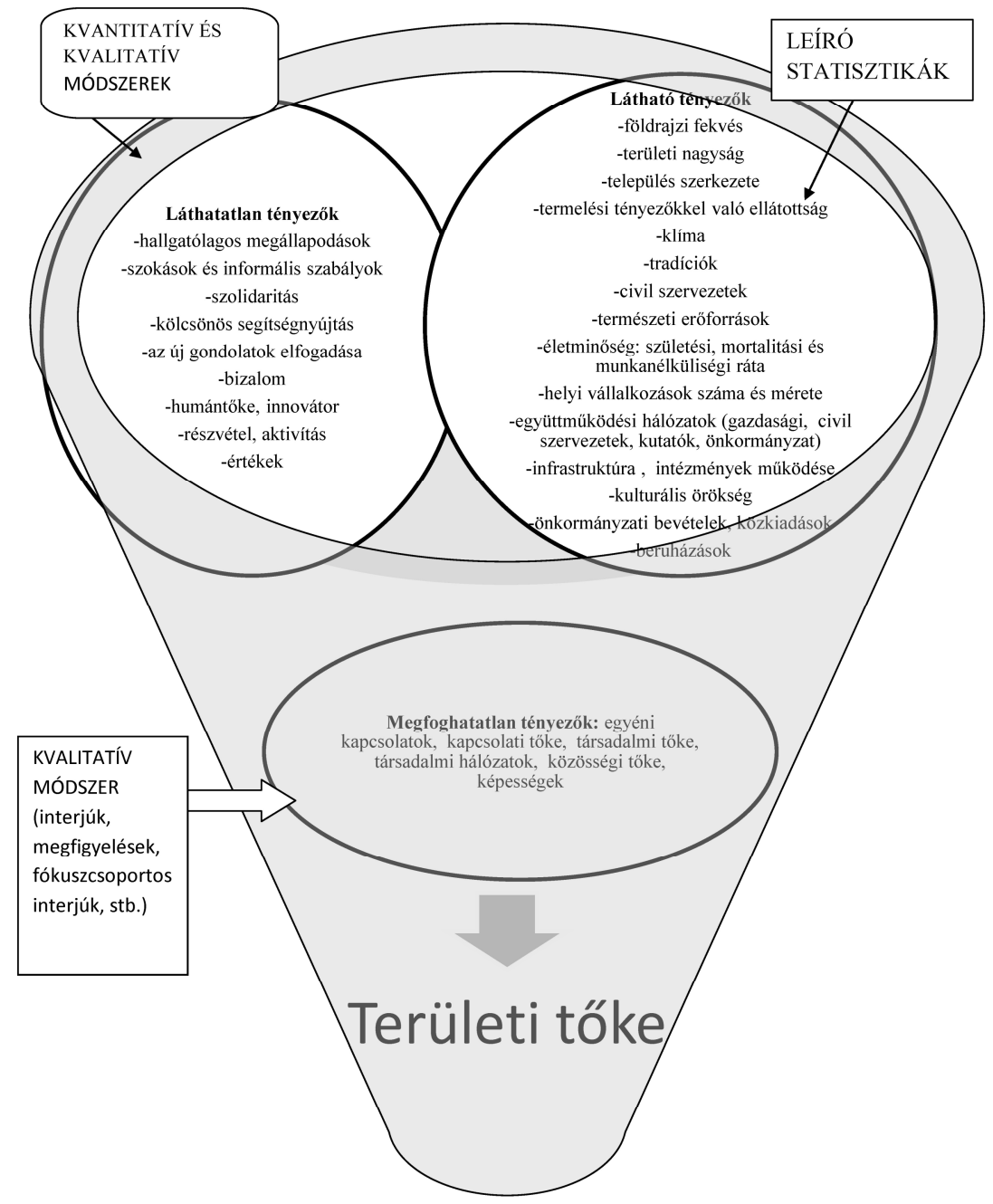

Forrás: Saját szerkesztés

2.ábra: Vidék, település területi tőkeelemei. 
A három fó csoport elkülönítve van egymástól, de mégis érintkeznek, kölcsönhatásba lépnek. A látható tényezőket a legkönnyebb megragadnunk, csupán a számadatokat kell elemeznünk meglévő statisztikai módszerekkel. A láthatatlan tényezők vizsgálatánál konceptualizálnunk és operacionalizálnuk kell, azaz definiálnunk kell a fogalmakat és mérhetővé kell tennünk, amennyiben az szükséges. A megfoghatatlan tényezők a nevükből adódóan is módszertanilag komplex eszközöket igényel, a kvalitatív módszer tárházát igényli, hogy mélységre ható, minőségi vizsgálat legyen. A megfoghatatlan tényezőket típusukból kifolyólag önmagukban nem lehet vizsgálni, csupán olyan tényezőkön keresztül, melyek láthatóak is. Például, ha kapcsolati tőkét kívánunk vizsgálni, akkor fontos megvizsgálnunk az adott térség civil szervezeteinek a kapcsolati, együttmüködési hálózatát, valamint ehhez kapcsolódó láthatatlan tényezőket, mint a bizalom, szolidaritás, kölcsönös segítségnyújtás, részvétel stb.

Látható, hogyan nagyon sokrétü vizsgálatot igényel egy település, térség területi tökéjének a feltérképezése. Jelenleg a módszertana kipróbálás alatt áll Napkor nagyközség falukutatás adatainak elemzésével. A részleges eredmények tükrében az már megállapítható, hogy a statisztikai mutatók kevesebbet mutatnak a településről, mint a valós állapot.

A vizsgálatok módszertanát, valamint a tőkeelemeket látván úgy is fogalmazhatunk, hogy a területi tőke nem is olyan újszerü a regionális, illetve a vidékkutatás tudományában. Talán ha van is újszerüsége, az abban van, hogy egy olyan új komplex gyüjtőfogalom, mellyel az adott terület gazdasági, földrajzi és társadalmi adottságait, mélyebb összefüggésrendszerét, vonzóképességét is lehet vizsgálni. A jelen tanulmány a vidéki területi tőke tanulmányozásához azzal járul hozzá, hogy e tőke elemeket a vidék adottságoknak megfelelően csoportosította és az eddig elterjedt módszerek során született következtetések hibáira hívja fel a figyelmet. Nem lehet egy térséget csupán leíró statisztikák, illetve MASST-modellel megismerni. A számok sok esetben nem tükrözik és nem is differenciálják az adott tér helyzetét. Kovács - Bodnár (2016) felhívják a figyelmünket arra, hogy a hasonló logikájú elemzések is más-más területi lehatárolás esetén eltérő eredményekhez vezetnek.

Így az is megállapítható, hogy puha tényezők minőségi (kvalitatív) mérését figyelmen kívül hagyva kevesebbet tudunk meg a vidéki térségeink adottságiról, illetve állapotáról. Tudva azt, hogy a belső erőforrások, mint például a helyi közösség tudatossága (mely számokkal nem kifejezhetőek), a materiális és immateriális javainak ismeretével tevékenységük során sokat tehetnek a lokális társadalmi jólétért a külső forrás hiány kiküszöbölésért.

„A területi tőke terület- vagy helyspecifikus erőforrás-portfólióra utal, a területrendszer sajátja, valamint lehetséges eszköz arra, hogy összetevőit értékes cselekedetekre válthassuk" (Tóth 2014, 5.o.). A területi tőkeelemek erőségének ismeretében az elmaradott térségek felzárkóztatásához mégis újszerü módon 
képes segítséget nyújtani, olyan erőforrást tesz láthatóvá, amelyek korábban nem, vagy csak kismértékben jelentek meg. Az endogén fejlödéshez, illetve az alulról szerveződő fejlesztési elképzelések megvalósításánál fontosak lehetnek a tőkeelemek ismeretei, adottságai. „A területi tőke koncepciójának kidolgozásával a régió versenyképességének javitása és a lokális társadalom jólétének növelése a cél" (Faludi 2006, 672.).

\section{Összegzés}

Jelen tanulmány bemutatja a tőkefajták sokszínüségét valamint e tőkék összességét kifejező területi tőkét. Kiemeli, hogy az eddig megalkotott területi tőke fogalom elemei és módszerei nem alkalmasak a vidéki térségek területtőkéjének mérésére, mert a tőkeelemek olyan tényezőket (GDP, K+F transzfer, egyetemi spinoff, PPP stb.) is tartalmaz, melyek vidéken nem mérhetőek, illetve nem léteznek. A területi tőke mérési módszertana leszükül ökonometriai, statisztikai elemzésekre.

A tanulmány áttekinti a magyar szakirodalmat és az utóbbi évtizedes kutatásokat a területi tőkével kapcsolatban. Megállapítja, hogy a tőkeelemeit a 1990-es évek óta kutatják. Ennek ellenére a területi töke fogalmával a szakma nem igazán tud mit kezdeni, ha meg is említik, de nem használják. Így a tanulmány szerzője szükségesnek érezte, hogy összeállítsa a vidék területi tőkeelemeit és vizsgálati módszerét. A vidéki területi tőke három fő tényezőből tevődik össze: látható, láthatatlan és megfoghatatlan. E tényezők szoros kapcsolatban van egymással, a látható és a láthatatlan beszivárog megfoghatatlan tényezőkbe.

A vidéki területi tőkeelemeinek csoportosítása és a mérésének a kidolgozása hozzá segít a magyar vidék adottságainak a feltérképezéséhez és az elmaradott térségek fejlesztéséhez.

\section{Irodalomjegyzék}

1. Beluszky P. - Győri R. (1999): A magyarországi városhálózat és az EUcsatlakozás. Tér és Társadalom, 1-2. 1-30.,

2. Bodor Á. - Grünhut Z. (2014): Dilemmák a területi tőke modelljének alkalmazhatóságáról - A társadalmi tőke problémája Camagni elméletében. Tér és Társadalom, 28/3., 3-17.

3. Bourdieu, P. (1978): A társadalmi egyenlőtlenségek újratermelődése. Gondolat, Budapest. 
4. Bourdieu, P. (1998): Gazdasági tőke, kulturális tőke, társadalmi tőke. In: Tőkefajták: A társadalmi és kulturális erőforrások szociológiája (Szerk.: Lengyel Gy. - Szántó Z.) Aula Kiadó, Budapest. 155-176.

5. Camagni, R. (2009): Territorial capital and regional development. In: Capello, R., Nijkamp, P. (eds.): Handbook of regional growth and development theories. Edward Elgar, Cheltenham, Northampton 118-132.

6. Capello, R. (2007): A forecasting territorial model of regional growth: the MASST model. The Annals of Regional Science, 4., 753-787.

7. Coleman, S. J. (1998): Social Capital in the Creation of Human Capital. American Journal of Sociology, 94; 95-120.

8. Czakó K. - Dőry T. (2016): A területi tőke koncepciója és a városi vállalkozáskutatás. Tér és Társadalom, 30/1., 18-35.

9. Csatári B. (2000): A magyarországi kistérségek vidékiség-kritériumai. In: Rechnitzer J., Horváth Gy., (szerk.): Magyarország területi szerkezete és folyamatai az ezredfordulón. MTA RKK, Pécs, 193-217.

10. Csurgó B. - Kovách I. - Megyesi B. (2009): Helyi hálózatok Európában és Magyarországon. Politikatudományi Szemle, 2; 120-141.

11. Csurgó B. - Légmán A. (2015): Lokális közösség, megtartó közösség. socio.hu 2015/4. DOl: 10.18030/socio.hu.2015.4.50

12. Enyedi Gy. (1997): A sikeres város. Tér és Társadalom. 11/4. 1-7.

13. Fabbro, S., Mesolella, A. (2010): Multilevel spatial visions and territorial cohesion: Italian regional planning between the TEN-T corridors, ESDP polycentrism and governmental 'Strategic Platforms' Planning, Practice \& Research, 1., 25-48.

14. Faludi, A. (2006): From European spatial development to territorial cohesion policy. Regional Studies, 6., 667-678.

15. Gáspár Gabriella (2001 [1986]): Hat falu hat sorsa. Pécs, Dr. Haller Média Kiadó,

16. Ignits Gy. - Kapitány B. (2006): „Elnéptelenedet” települések Baranyában. Területi Statisztika 46/2., 135-150.

17. Jóna Gy. (2013): A területi tőke fogalmi megközelítései. Tér és Társadalom 27 évf., 1. szám 30-51.

18. Jóna Gy. (2016): A koopetitív kkv-hálózatok területi dimenziói és hatásai. Területi Statisztika, 56. évf., 1 szám; 66-89.

19. Kis K. (2006): A társadalmi tőke mint a társadalmi és gazdasági folyamatokat befolyásoló erőforrás. Agrártudományi Közlemények, 20; 69-73.

20. Kovács K. (2005): Osztályosodás a magyar településhálózatban. Kultúra és Közösség, 3-4; 21-26.

21. Kovács P.- Bodnár G. (2016): Az endogén fejlődés értelmezése vidéki térségekben PLS-útelemzés segítségével. Statisztikai Szemle, 94.évf. 2.szám 143-161. 
22. Kovács T. (2003): Vidékfejlesztési politika. Dialóg Campus Kiadó, Budapest-Pécs.

23. Kovács T: (2008): Gazdaportrék. Agroinform Kiadó, Budapest.

24. Kuczi T. (1998): Vállalkozói kultúra-az életutak finalitása. Replika, 29 (március) 157-170.

25. Kunzmann, K. R. (2011): After the global economic crisis: policy implications for the future of the European territory. Informationen zur Raumentwicklung, 8., 601-612.

26. Lengyel I. (2012): A hazai területfejlesztés zsákutcái: a triális Magyarország. In Rechnitzer J. - Rácz Sz. (szerk.): Dialógus a regionális tudományról. Széchenyi István Egyetem Regionális- és Gazdaságtudományi Doktori Iskola, Magyar Regionális Tudományi Társaság. Győr140-150.

27. Letenyei (1999): Rendszerváltozás után. In Borsos E. és társai: Rendszerváltozás után. Falusi sorsforduló a Kárpát-medencében. Budapest: MTA PTI-Számalk, 15-48.

28. Lin, N. (1999): Building a network: theory of social capital. Connections, 22/1. 28-51.

29. Ludescher G. (2010): A vállalkozások és a közösségek szerepe a rurális térségek megújulásában. Pécs, Publikon Kiadó.

30. McManus, P. és társai (2012): Rural community and rural resilience: what is important to farmer sin keeping their country towns alive? Journal Rural Studies 28, 20-29.

31. MTA és MNVH (2013): Vidékkutatás 2012-2013. http://www.mnvh.eu/node/591359 (Letöltés 2015. december 12.)

32. Novotny G. (2003): Határon átnyúló városhálózatok: újabb intézményi divat az európai határon átnyúló együttmüködésekben? Tér és Társadalom, 1; 191-212.

33. OECD (2001): OECD Territorial Outlook, Territorial Economy. http://www.vwl.tuwien.ac.at/hanappi/AgeSo/SecReps/Territorial_Outlook_ F.pdf (Letöltés 2016. március 01.)

34. Perger É. (2015): A Magyar Tudományos Akadémia és a Magyar Nemzeti Vidéki Hálózat együttműködése keretében megvalósult komplex vidékkutatási programról. Tér és Társadalom, 29/1., 3-10.

35. Putnam, R. D. (2000): Bowling alone: the collapse and revival of American community. New York, Simon \& Schuster.

36. Rechnitzer J. (2002): A városhálózat az átmenetben, a kilencvenes évek változási irányai. Tér és Társadalom, 2002/3., 165-184.

37. Rechnitzer J. - Grosz A. - Csizmadia Z. (2003): A magyar városhálózat tagozódása az info-kommunikációs infrastruktúra alapján az ezredfordulón. Tér és társadalom, 2003/3., 145-165. 
38. Rota, F. S. (2010): The territorial embedment of global industrial networks. Theoretical insights and evidences from foreign MNCs' affiliates in Turin (Italy).

http://citeseerx.ist.psu.edu/viewdoc/download?doi=10.1.1.169.7598\&rep $=\mathrm{r}$ ep1\&type=pdf (Letöltés: 2016. január 10.)

39. Sánchez-Zamora, P. - Gallardo-Cobos, R. - Ceňa-Delgado, F. (2014): Rural areas face the economic crisis: Analyzing the determinants of successful territorial dynamics. Journal of Rural Studies, 35, 11-25.

40. Stein, A. (2010): Territorial cohesion in the context of interregional and transnational cooperation. European Spatial Research and Policy, 1. 5-22.

41. Steiner, A. - Atterton, J. (2015): Exploring the contribution of rural enterprises to local resilience. Journal of Rural Studies, 40; 30-45.

42. Szörényiné Kukorelli I. (1997): A kistérségek gazdasági és társadalmi jellemzői és trendjei az Észak-Dunántúlon. Tér és Társadalom 11/1., 147-181.

43. Tóth B. I. (2010): Az immateriális és a területi tőke összefüggései. Tér és Társadalom, 1., 65-81.

44. Tóth B. I. (2011): A magyar középvárosok teljesítménye a területi tőke tükrében. Területi Statisztika, 51/5., 530-543.

45. Tóth B. I. (2013): A területi tőke szerepe a regionális- és városfejlődésben Esettanulmányok a hazai középvárosok példáján. Doktori értekezés. Nyugat-magyarországi Egyetem, Sopron.

46. Tóth B. I. (2014): A hazai kistérségek vonzerejének és területi tőkéjének néhány összefüggése. Területi Statisztika, 54/1. 3-18.

47. Veneri, P. (2011): Territorial identity in Italian NUTS-3 regions. http://www.grupposervizioambiente.it/aisre/pendrive2011/pendrive/paper/p aper_vert_an_june_2011.pdf (letöltve: 2016. február 20.)

48. Wilson, G. A., (2012): Community Resilence and Environmental Transitions. Routledge, London.

49. Zonnenveld, W. - Waterhout, B. (2005): Visions on territorial cohesion. The Town Planning Review, 1., 15-27.

50. Zonnenveld, W. - Waterhout, B. (2010): Implnatications of territorial cohesion: an essay. Paper prepared for the Regional Studies Association Annual International Conference, Pécs, május 24-26. 
